\title{
AKURASI MODEL LOGISTIK SPRINGATE, ZMIJEWSKI, DAN GROVER DALAM MENAKAR KESULITAN KEUANGAN PERUSAHAAN PEMBIAYAAN
}

\author{
Munawarah \& Keumala Hayati \\ Fakultas Ekonomi, Prodi Akuntansi, Universitas Prima Indonesia \\ Medan, Indonesia \\ e-mail: munawarah1710@yahoo.com
}

\begin{abstract}
This study aims to determine springate, grover, and zmijewski able to predict the condition of financial distress in finance companies listed on the Indonesia Stock Exchange. From three models can be known which model is the most accurate in predicting financial distress. There are 17 companies in financing sector as population in this study from 2013-2017. Using purposive sampling technique, total sample of 85 financing companies was obtained. Secondary data were used in this research sourced from the company's annual reports. The analysis model used is logistic regression. Simultaneously, all predictive models affect the probability offinancial distress. While partially only Zmijewski can influence the prediction of financial distress conditions in financing sub-sector companies listed on the Indonesia Stock Exchange. Nagelkerqe Square value shows 0.606 meaning that only $60.6 \%$ variation of the accuracy of these three models in predicting financial distress conditions of finance companies. While $39.4 \%$ can be explained by other models not examined in this study.
\end{abstract}

Keywords: springate model, zmijewski model, grover model, financial distress

\section{PENDAHULUAN}

Perusahaan pembiayaan pada awalnya merupakan perusahaan yang hanya bergerak dalam kegiatan sewa guna usaha. Namun tidak dapat dipungkiri kehadiran perusahaan pembiayaan di Indonesia dua puluh tahun terakhir ini mengalami perkembangan yang pesat. Sebagai perusahaan yang meramaikan industri keuangan dan telah dikenal masyarakat Indonesia, keberadaan perusahaan ini mampu mendorong pertumbuhan ekonomi di Indonesia melalui kegiatan pembiayaan konsumen dalam pengadaan berbagai macam barang seperti elektronik, kendaraan roda dua, roda empat, dan lainnya. Tak dapat dipungkiri, industri pembiayaan ini juga mendorong tumbuhnya industri otomotif dan industri perbankan.

Semakin berkembang pesatnya industri ini diperlukan suatu pengawasan dan menetapkan regulasi terkait dengan aktivitas pembiayaan yang dilakukan. Tingkat kesehatan perusahaan pembiayaan perlu diawasi oleh OJK mengingat selama ini persepsi yang ada bahwa industri ini berkaitan dengan "shadow banking" karena dianggap masih belum mandiri dalam hal kecukupan modalnya yang sebagian besar berasal dari dana yang dikucurkan perusahaan perbankan.

Perusahaan pembiayaan merupakan bisnis yang berbeda jika dibandingkan dengan perusahaan non-jasa keuangan lainnya. Perusahaan jenis ini memiliki rasio leverage yang cukup tinggi karena penggunaan utang sebagai sumber modal yang banyak berasal dari perbankan dan dibandingkan dengan modal sendiri. Hal ini menyebabkan struktur aktiva dan kewajiban perusahaan menjadi tidak seimbang. Dengan demikian, tidak 
dapat dipungkiri perusahaan pembiayaan ini rentan terhadap risiko, terutama risiko likuiditas, akibat komposisi aset dan liabilitas yang tidak berimbang. Sebagian besar sumber dana yang diperoleh dari perbankan umumnya bersifat jangka pendek, sementara pembiayaan yang dilempar ke pasar umumnya berjangka menengah. Jika tidak diatasi, akan berdampak pada kegagalan perusahaan pembiayaan mengingat perusahaan ini dipandang sebagai lembaga kepercayaan.

Dalam hal pemberian pinjaman dengan jangka waktu satu tahun atau lebih, diperlukan seorang analis untuk menganalisis serta memberikan opini atas risiko pembiayaan yang muncul. Setiap ketidakpastian yang muncul terkait dengan pengelolaan perusahaan pembiayaan, akan berpotensi memberi dampak terhadap keuangan perusahaan. Dalam menilai risiko perusahaan pembiayaan Pasal 4 ayat (2) Peraturan Otoritas Jasa Keuangan Nomor 10/POJK.05/2014 menyebutkan salah satu risiko yang kerap terjadi adalah risikolikuiditas. Risiko ini terjadikarena adanya potensi kegagalan dalam mengelola aset dan liabilitas yang berdampak pada kurangnya dana dalam memenuhi kewajiban perusahaan. Selain itu risiko pembiayaan juga menjadi faktor penentu kesehatan suatu perusahaan pembiayaan, yang terjadi akibat kegagalan debitur dalam melunasi kembali kewajiban angsuran atas pembiayaan yang sudah diterima ditandai dengan membengkaknya rasio pembiayaan bermasalah (Non Performing Financing (NPF). Hal ini menjadi risiko terbesar yang dapat menyebabkan kesulitan keuangan bagi perusahaan pembiayaan, karena sebagian besar aset perusahaan merupakan piutang pembiayaan dari debitur.

Pada akhirnya, kondisi seperti ini membuat perusahaan pembiayaan rentan menghadapi kesulitan keuangan atau disebut financial distress akibat dari ketidakmampuan perusahaan dalam hal pengelolaan dan stabilisasi performa keuangan. Kegagalan perusahaan dalam mengelola kualitas aktiva produktif dapat menyebabkan turunnya tingkat kolektabilitas tagihan pembiayaan yang mengakibatkan hilangnya potensi perusahaan mendapatkan pendapatan operasional. Selain itu, perusahaan akan berpotensi menderita defisit keuangan pada tahun berjalan. Defisit keuangan akan menyebabkan penurunan modal karena pengurangan laba.

Kerugian yang terjadi akan menyebabkan defisiensi modal karena penurunan saldo laba. Laba banyak tergerus dalam membayar pokok dan bunga pinjaman, dan akibatnya total ekuitas sebagai sumber modal juga akan mengalami penurunan secara keseluruhan. Efeknya total kewajiban akan jauh melebihi total aset pada perusahaan pembiayaan. Pada akhirnya kondisi dapat menyebabkan perusahaan pembiayaan mengalami kesulitan keuangan dan jika tidak mampu segera mengatasinya, akan berdampak pada kepailitan.

Model prediksi kesulitan keuangan menjadi hal penting yang harus dipertimbangkan sebab banyaknya pihak terkait dalam perusahaan pembiayaan. Sebagai perusahaan yang hanya memberikan jasa pembiayaan atau kredit, menyebabkan perusahaan banyak bergantung kepada pihak lain seperti kreditor, perbankan, dealer, vendor, merchant, dan lainnya. Pembayaran debitur yang macet maupun kerugian finansial lainnya akan menunjukkan kesulitan keuangan dan menjadi pusat perhatian bagi pihak manajemen.

Ada banyak model prediksi yang telah diteliti oleh peneliti sebelumnya seperti Model Springate, Zmijewski, dan Grover. Model-model ini merupakan model modifikasi dari model Altman dengan menggunakan teknik Multiple Discriminant Analysis (MDA), yaitu berbagai rasio keuangan yang dapat memprediksi kesulitankeuangan. 
Hasil penelitian dari masing-masing model ini masih memiliki banyak perbedaan. Prihantini (2013) menyatakan bahwa tingkat kesulitan keuangan pada perusahaan sektor makanan dan minuman lebih sesuai diprediksi dengan Model Grover. Sejalan dengan model penelitian Syahfitriani (2017) juga menyatakan model Grover yang paling tepat untuk memprediksi kondisi kebangkrutan pada perusahaan pertambangan. Sedangkan menurut Adriana dan Nasir (2012) menyatakan berdasarkan hasil penelitian mereka justru model Grover yang mempunyai tingkat akurasi paling tinggi sebesar 92,5\% untuk memprediksi kondisi financial distress atau potensi kebangkrutan perusahaan. Berdasarkan uraian tersebut maka perlu dirumuskan kembali di antara ketiga model Springate, Zmijewski, dan Grover dapat memperkirakan kondisi kesulitan keuangan pada perusahaan Pembiayaan serta model manakah yang paling akurat dalam memprediksi kondisi kesulitan keuangan.

\section{TINJAUAN PUSTAKA}

\section{Kinerja Perusahaan}

Kinerja perusahaan merupakan gambaran kondisi perusahaan yang salah satunya dapat dilihat dari kinerja keuangan. Kinerja keuangan dapat diukur melalui indikator keuangan pada rasio keuangan di antaranya rasio likuiditas, solvabilitas, rentabilitas, dan aktivitas.

Syahyunan (2013) menjelaskan pengertian berbagaijenis rasio keuangan sebagai pengukuran kinerja perusahaan sebagai berikut. Likuiditas sering disebut sebagai rasio lancar, yang mengukur tingkat kelancaran perusahaan untuk menyelesaikan kewajiban yang akan jatuh tempo dalam waktu dekat. Likuiditas merupakan rasio yang menjelaskan interaksi antara aset lancar perusahaan dibandingkan kewajiban lancarnya.
Solvabilitas dipergunakan untuk mengetahui bagaimana komposisi pendanaan perusahaan baik yang berasal dari utang maupun modal dalam mendanai usahanya. Pengukuran rasio aktivitas dipergunakan perusahaan dalam efektivitas pengelolaan aset yang dimiliki untuk melaksanakan aktivitasnya. Dan yang terakhir merupakan rasio rentabilitas sebagai pengukuran seberapa efektif pihak manajemen perusahaan dalam menghasilkan laba sebagai tujuan perusahaan.

\section{Kesulitan Keuangan}

Kesulitan Keuangan(Financial Distress) menurut Wijoyo (2016) terjadi saat suatu perusahaan tidak mampu memenuhi jadwal pembayaran atau ketika proyeksi arus kas mengindikasikan bahwa perusahaan tersebut akan segera tidak dapat memenuhi kewajibannya.

\section{Landasan Teori Kesulitan Keuangan}

Kesulitan keuangan berawal dari dilakukannya studi mengenai struktur modal. Salah satu teori struktur modal yang erat kaitannya adalah teori trade off (static trade of theory) yang menyatakan bahwa perusahaan dapat memanfaatkan sumber pendanaan yang berasal dari luar seperti utang, dan memperhatikan manfaat pajak atas utang yang dilakukan haruslah lebih besar dari biaya yang ditimbulkan. Teori ini menyebabkan banyak akademisi untuk menggabungkan ukuran kemungkinan kesulitan keuangan (financial distress likelihood). Namun menjadi sebuah catatan jika manfaat utang yang menimbulkan bunga sebagai pengurang pajak justru tidak terkelola dengan baik. Optimalisasi tingkat solvabilitas perusahaan pada titik tertentu untuk menghasilkan laba terabaikan sehingga, biaya kesulitan akan jauh lebih besar sehingga berujung pada kebangkrutan suatu perusahaan. 


\section{Model Prediksi Kebangkrutan}

\section{Model Springate}

Merupakan hasil penelitian yang dilakukan oleh Gordon L. Springate di tahun 1978 dengan sampel perusahaan di Kanada. Beliau mengukur kesulitan keuangan berdasarkan rasio keuangan perusahaan pada rumus berikut:

$\mathrm{S}-\mathrm{Score}=1,03 \mathrm{X} 1+3,07 \mathrm{X} 2+0,66 \mathrm{X} 3+0,4 \mathrm{X} 4$

Keterangan:

$\mathrm{X} 1=$ Working Capital to Total Asset

$\mathrm{X} 2=$ EBIT to Total Asset

$\mathrm{X} 3=$ EBT to Current Liabilities

$\mathrm{X} 4=$ Sales to Total Asset

Cut-off nilai yang ditetapkan sebesar 0,862. Nilai $\mathrm{S}<0,862$ menunjukkan bahwa perusahaan tersebut diprediksi akan menderita kebangkrutan. Sebaliknya jika nilai S-Score $>0,862$ maka perusahaan dikategorikan sehat.

\section{Model Zmijewski}

Zmijewski melakukan penelitian tahun 1983 dengan rentang waktu riset selama 20 tahun. Zmijewski menyatakan bahwa rasio rentabilitas, likuiditas dan solvabilitas sebagai variabel terpenting dalam memprediksi kemungkinan bangkrutnya perusahaan. Sebanyak 148 perusahaan dijadikan sebagai sampel dengan kategori 75 perusahaan mengalami financial distress, dan 73 perusahaan lainnya dalam kondisi sehat dari tahun 1972-1978. Hasil penelitian beliau diperoleh rumus sebagai berikut: $\mathrm{X}$-Score $=-4,3-4,5 \mathrm{X}_{1}+5,72 \mathrm{X}_{2}-0,004 \mathrm{X}_{3}$

Keterangan:

$\mathrm{X} 1=$ Return on Asset (ROA) $\mathrm{X}_{2}$

$=$ Debt to Asset Ratio (DAR) $\mathrm{X}_{3}$

$=$ Current Ratio

Jika nilai X-Score $>0$ perusahaan diduga menderita kesulitan keuangan. Jika nilai X-Score
$<0$ perusahaan diduga tidak berpotensi untuk mengalami kesulitan keuangan.

\section{Model Grover}

Jeffrey S. Grover telah melakukan penelitian pada tahun 2001 dan sampel yang digunakan sama seperti pada model Altman, sebanyak 70 perusahaan dengan klasifikasi ada 35 entitas yang berpotensi mengalami kesulitan keuangan, dan sisanya tidak. Grover menambahkan 13 rasio keuangan baru untuk melihat kondisi perusahaan pada tahun 1982-1996. Hasil penelitian tersebut, diperoleh rumus model Grover seperti:

G-Score $=1,65 \times 1+3,404 \times 2-0,016$ X3 +0,057 Keterangan:

$\mathrm{X} 1=$ Working Capital to Total Asset

X2 = Earning Before Interest and Tax to Total Asset $\mathrm{X} 3=$ Net Income Tax to Total Asset

Perusahaan dikategorikan bangkrut atau mengalami financial distress jika nilai G-Score $\leq-0,02$. Sebaliknya perusahaan dikategorikan sehat dan tidak mengalami financial distress jika nilai G-Score $\geq 0,01$.

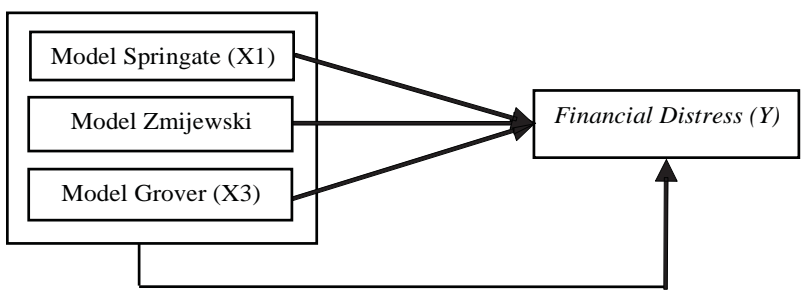

\section{Kerangka Konseptual dan Hipotesis}

Berdasarkan kerangka konseptual dan uraian model prediksi kebangkrutan yang digunakan maka dapat dikembangkan Hipotesis penelitian dari penggunaan Model Springate melalui S-Score, Model Zmijewski melalui Xscore dan Model Grover melalui G-score dapat 
memprediksi probabilitas terjadinya kondisi kesulitan keuangan dan mana yang paling akurat dalam menduga kondisi tersebut pada perusahaan pembiayaan tergabung di Bursa Efek Indonesia Tahun 2013-2017.

\section{METODE PENELITIAN}

Ada sebanyak 17 perusahaan yang tergabung pada sub sektor lembaga pembiayaan di Bursa Efek Indonesia tahun 2013-2017 dan dijadikan populasi penelitian.

Untuk pengambilan sampel, teknik purposive sampling dipakai dengan kriteria: (1) Lembaga pembiayaan yang terdaftar secara berturutturut di Bursa Efek mulai tahun 2013-2017. (2) Lembaga pembiayaan yang menyajikan laporan keuangan tahunan yang sudah diaudit berturutturut tahun 2013-2017. Total sampel diperoleh 15 perusahaan dikali 5 tahun pengamatan menjadi 75 perusahaan.

Data sekunder digunakan dalam penelitian, karena menggunakan data-data keuangan yang diperoleh dari laporan keuangan tahunan perusa haan pembiayaan tahun 2013 sampai 2017. Pendekatan penelitian menggunakan deskriptif kuântitatif.

\section{Identifikasi Variabel Penelitian}

1. Variabel independen

Yang menjadi variabelindependen adalah model prediksi kesulitan keuangan terdiri dari model Springate, Zmijewski, dan Grover dengan penjelasan masing-masing rasio sebagai berikut.

a. Working Capital to Total Asset adalah bagian dari rasio perputaran modal kerja untuk memahami bagaimana efektivitas manajemen mengelola aktiva yang dimiliki sebagai modal kerja dalam kegiatan perusahaan.

Rumus:

Working capital turnover $=\frac{\text { Working Capital }}{\text { Total Asset }}$

b. EBIT to Total Asset sering disebut juga rasio rentabilitas ekonomi untuk mengetahui seberapa efektif pengelolaan aktiva untuk dapat menghasilkan laba perusahaan.

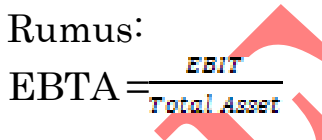

c. EBT to Current Liabilities adalah bagian dari tingkat likuiditas yang mengukur kemampuan perusahaan dalam menyelesaikan kewajiban jangka pendeknya tepat waktu sebelum jatuh tempo dari laba yang dihasilkan.

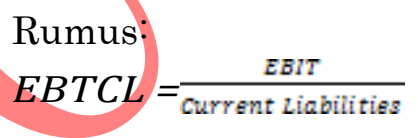

d. Sales to total asset merupakan bagian rasio yang mengukur seberapa efektif manajemen dalam menggunakan aktiva yang dimiliki dalam kegiatan perusahaan.

Rumus:

Total Asset turnover $=\frac{\text { sales }}{\text { total Asset }}$

e. Return on Asset merupakan bagian dari tingkat rentabilitas diukur melalui perbandingan antara laba bersih setelah pajak dibagi dengan total aktiva perusahaan. Rumus:

$$
R O A=\frac{\text { Earning After } T a x}{\text { Total Asset }}
$$

f. Debt to Asset Ratio merupakan bagian dari tingkat leverage (solvabilitas) yang mengukur kemampuan perusahaan dalam melunasi seluruh utang-utangnya. Dengan membandingkan total utang dengan total aktiva perusahaan. 
Rumus:

$$
D A R=\frac{\text { Total Debt }}{\text { Total Asset }}
$$

g. Current Ratio adalah bagian tingkat $\mathrm{Li}^{-}$ kuiditas yang mengukur kemampuan perusahaan dalam menyelesaikan kewajiban jangka pendeknya tepat waktu atau sebelum jatuh tempo.

Rumus:

Current Ratio $=\frac{\text { current Asset }}{\text { current liabilities }}$

2. Variabel dependen yang digunakan adalah tingkat kesulitan keuangan karena menurunnya kondisi keuangan perusahaan sebelum dinyatakan bangkrut. Variabel dependen merupakan variabel dikotomi (dummy) karena memiliki kategori berdasarkan kondisi yang terjadi. Nilai "0" diberikan jika perusahaan mengalami financial distress dengan indikasi mengalami kerugian lebih dari satu tahun dan dividen tidak dibayarkan secara teratur. Sedangkan nilai "1" diberikan jika perusahaan tidak mengalami financial distress dilihat dari perolehan laba dan pembayaran dividennya.

\section{HASIL PENELITIAN DAN PEMBAHASAN}

\section{Statistik Deskriptif}

Tabel 1 Descriptive Statistics

\begin{tabular}{|l|c|c|c|c|c|}
\hline & N & Min & Max & Mean & $\begin{array}{c}\text { Std. } \\
\text { Deviation }\end{array}$ \\
\hline SPRINGATE & 75 & -.756 & 2.1010 & .71997 & .43245 \\
ZMIJEWSKI & 75 & -5.887 & 84.4990 & 15.3452 & 14.6743 \\
GROVER & 75 & -1.064 & 2.0807 & .9063 & .54833 \\
Valid N (listwise) & 75 & & & & \\
\hline
\end{tabular}

Sumber: Data diolah peneliti (2018)

Tabel di atas menunjukkan nilai maksimum dari model Springate adalah sebesar 2,1010 dan nilai minimum sebesar - 0,756 . Model Zmijewski menunjukkan nilai maksimum sebesar .84,499 dan nilai minimum sebesar -5,887. Dan pada model Grover menunjukkan nilai maksimum sebesar 2,0807 dan nilai minimum sebesar -1,064.

\section{Uji Hosmer and Lemeshow Test (Goodness of Fit Test)}

Tabel 2 Hosmer and Lemeshow Test

\begin{tabular}{|c|c|c|c|}
\hline Step & Chi-square & df & Sig. \\
\hline 1 & 6.871 & 7 & .442 \\
\hline
\end{tabular}

Sumber: Data diolah peneliti (2018)

Tabel di atas menunjukkan nilai Chi square sebesar 6,871 dan nilai degree of freedom (df) 7 dengan nilai signifikansi 0,442>0,05. Artinya, model regresi logistik dianggap fit dan sesuai sehingga dapat digunakan untuk uji selanjutnya.

\section{Uji Overall Model Fit}

\section{Tabel 3 Overall Model Fit beginning Block}

(Block =0)

Iteration History ${ }^{a, b, c}$

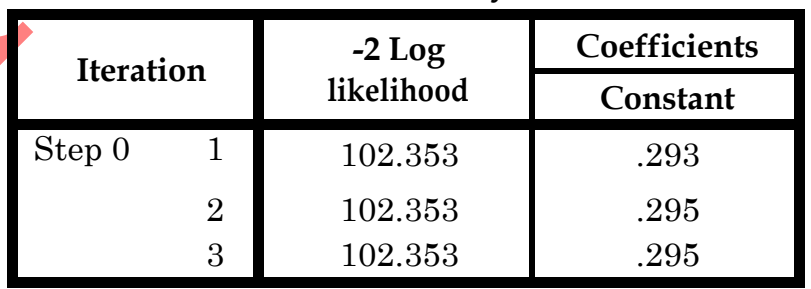

Sumber:Data diolah peneliti (2018)

Tabel 4 Hasil Uji Overall Model Fit Beginning Block (Block =1)

\begin{tabular}{|r|c|c|c|c|c|}
\hline \multirow{2}{*}{ Iteration } & \multirow{2}{*}{$\begin{array}{c}\mathbf{- 2} \mathbf{L o g} \\
\text { likelihood }\end{array}$} & \multicolumn{4}{|c|}{ Coefficients } \\
\cline { 3 - 6 } & & Constant & $\begin{array}{c}\text { SPRING } \\
\text { ATE }\end{array}$ & $\begin{array}{c}\text { GROVE } \\
\mathbf{R}\end{array}$ & $\begin{array}{c}\text { ZMIJE } \\
\text { WSKI }\end{array}$ \\
\hline Step 1 1 & 61.373 & 1.475 & 2.162 & -1.290 & -.108 \\
& 57.639 & 2.106 & 3.702 & -2.378 & -.152 \\
3 & 57.386 & 2.334 & 4.470 & -2.957 & -.168 \\
4 & 57.384 & 2.358 & 4.570 & -3.035 & -.169 \\
5 & 57.384 & 2.358 & 4.572 & -3.036 & -.169 \\
6 & 57.384 & 2.358 & 4.572 & -3.036 & -.169 \\
\hline
\end{tabular}

Sumber: Data diolah peneliti (2018) 
Nilai -2 LL pada blok pertama sebesar 102,353. Sedangkan nilai 2LL pada blok kedua sebesar 57,384. Halini dapat menjelaskan bahwa ketika model hanya dengan konstanta saja tanpa adanya variabel bebas menunjukkan penurunan dari 102,353 menjadi 57,384. Penurunan model keseluruhan (Overall model fit) pada 2 Log likelihood block number $=0$ ke -2 Log likelihood block number $=1$ sebesar 44,969. Dapat disimpulkan penurunan nilai likelihood menunjukkan model penelitian dinyatakan fit atau layak. Artinya model yang telah dihipotesiskan fit dengan data.

\section{Koefisien Determinasi (Nagelkerke R Square)} Tabel 5 Koefisien Determinasi

\begin{tabular}{|c|c|c|c|}
\hline Step & $\begin{array}{c}\mathbf{- 2} \text { Log } \\
\text { likelihood }\end{array}$ & $\begin{array}{c}\text { Cox \& Snell } \\
\text { R Square }\end{array}$ & $\begin{array}{c}\text { Nagelkerke R. } \\
\text { Square }\end{array}$ \\
\hline 1 & $57.384^{\mathrm{a}}$ & .451 & .606 \\
\hline
\end{tabular}

Sumber: Data diolah peneliti (2018)

Hasil tabel tersebut menunjukkan bahwa nilai uji-2 Log Likelihood sebesar 57,384. Nilai Nagelkerke $R$ Square 0,606, dapat dikatakan variabilitas variabel independen untuk menjelaskan variabel dependennya adalah sebesar 60,6 \%. Sisanya sebesar $39,4 \%$ dapat dijelaskan oleh faktor-faktor lain yang tidak diikutsertakan dalam model penelitian.

\section{Uji Simultan (F test)}

Tabel 6 Omnibus Test of Model Coefficient

\begin{tabular}{|ll|c|c|c|}
\hline & & Chi-square & df & Sig. \\
\hline Step 1 & Step & 44.969 & 3 & .000 \\
& Block & 44.969 & 3 & .000 \\
& Model & 44.969 & 3 & .000 \\
\hline
\end{tabular}

Sumber: Data diolah peneliti (2018)
Chi Square bernilai 44,969 dengan derajat kebebasan adalah 3, dan signifikansi di bawah 0,05. Disimpulkan bahwa model Springate, Zmijewski, dan Grover secara simultan berpengaruh signifikan dengan kondisi kesulitan keuangan lembaga atau perusahaan pembiayaan di Bursa Efek Indonesia.

\section{Uji Individual (Uji Parsial t-Test)}

Tabel 7 Pengujian Koefisien Regresi

\begin{tabular}{|cc|c|c|c|c|c|c|}
\hline & & B & S.E. & Wald & df & Sig. & Exp(B) \\
\hline SStep 1 ${ }^{\text {a }}$ & SPRINGATE & 4.572 & 4.447 & 1.057 & 1 & .304 & 96.698 \\
& & & & & & \\
ZMIJEWSKI & -.169 & .038 & 20.240 & 1 & .000 & .844 \\
GROVER & -3.036 & 3.464 & .768 & 1 & .381 & .048 \\
Constant & 2.358 & .925 & 6.504 & 1 & .011 & 10.574 \\
\hline
\end{tabular}

Sumber:Data diolah peneliti (2018)

Berdasarkan hasil uji koefisien regresi, dapat diperoleh persamaan regresi logistik menjadi sebagai berikut.

$$
\begin{aligned}
\operatorname{Ln} \frac{p}{1-p}= & 2,358+4,572 \text { Springate }-0,169 \\
& \text { Zmijewski }-3,036 \text { Grover }
\end{aligned}
$$

Hasil persamaan di atas dapat diinterpretasikan bahwa nilai konstanta positif 2,358. Disimpulkan jika semua variabel diabaikan maka peluang terjadinya debitur macet justru akan meningkat. Nilai signifikansi konstanta 0,011 yang berarti signifikan terhadap probabilitas kesulitan keuangan (financial distress).

Koefisien Springate memiliki tanda positif dengan nilai sebesar 4,572. Artinya setiap kenaikan model Springate sebesar satu satuan akan menaikkan peluang terjadinya kesulitan keuangan (financial distress). Dengan nilai signifikansi 0,304 menunjukkan pengaruh variabel ini tidak signifikan terhadap probabilitas terjadinya financial distress. 
Koefisien Zmijewski memiliki tanda negatif sebesar -0,169. Artinya, setiap kenaikan model Zmijewski sebesar satu satuan akan menurunkan peluang terjadinya kesulitan keuangan (financial distress). Dengan nilai signifikansi 0,00 menunjukkan model Zmijewski ini berpengaruh signifikan terhadap probabilitas terjadinya financial distress.

Koefisien Grover memiliki tanda negatif sebesar -3,036. Artinya setiap kenaikan model ini sebesar satu satuan akan menurunkan peluang terjadinya financial distress Dengan nilai signifikansi 0,381 menunjukkan pengaruh variabel ini tidak signifikan terhadap probabilitas terjadinya financial distress.

\section{Klasifikasi Data Penelitian}

Tabel 4.8 Klasifikasi Model Analisis

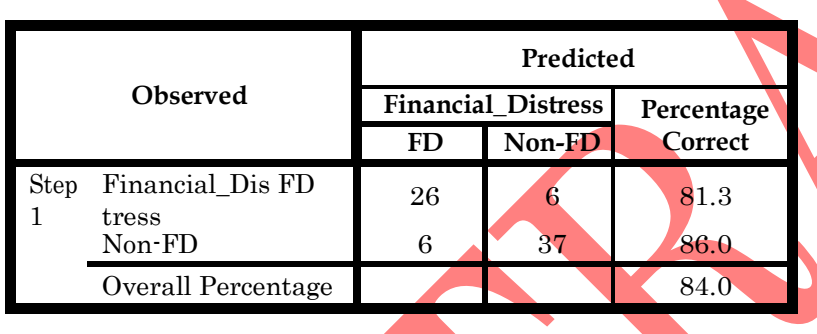

Sumber: Data diolah peneliti (2018)

Pada kolom prediksi klasifikasi perusahaan pembiayaan yang menderita kesulitan keuangan sebanyak 32 sedangkan pada nilai observasi yang sesungguhnya diperoleh hanya 26 perusahaan. Ini berarti ketepatan model prediksi hanya mampu menyumbang angka $81,3 \%$. Sementara pada kolom prediksi perusahaan yang tidak mengalami kesulitan keuangan ada sebanyak 43 sedangkan pada pengamatan yang sebenarnya diperoleh 37 perusahaan. Maka persentase ketepatan model prediksi sebesar $86 \%$. Secara keseluruhan dapat disimpulkan bahwa ketepatan model prediksi sebesar $84 \%$.

\section{Pembahasan}

Berdasarkan hasil uji parsial diperoleh hanya model Zmijewski memiliki nilai signifikansi sebesar 0,000 artinya variabel ini memiliki pengaruh positif dan signifikan terhadap probabilitas kesulitan keuangan pada perusahaan pembiayaan. Hasil ini mendukung hipotesis yang menyatakan Model Zmijewski berpengaruh signifikan terhadap probabilitas terjadinya kesulitan keuangan Hal ini dapat disebabkan karena pada model ini, rasio keuangan yang diukur tidak hanya terlihat dari rasio laba saja, namun berasal dari komponen rasio leverage (solvabilitas) dan rasio likuiditas. Hasil ini sesuai dengan fungsi utama manajemen keuangan yaitu perusahaan yang mampubertahan adalah perusahaan yang mampu menjaga keseimbangan komposisi keuangan yang ditandai dari 4 rasio keuangan utama yaitu rasio profitabilitas, solvabilitas, likuiditas, dan aktivitas. Tiga di antara rasio tersebut merupakan rasio utama dalam melihat kondisi keuangan perusahaan. Oleh karena itu manajer lebih teliti dalam menafsirkan dan menganalisis rasio keuangan tersebut. Tidak hanya manajer, banyak pihak yang membutuhkannya seperti investor, kreditor, dan pihak lainnya. Pada perusahaan pembiayaan, seringkali yang menjadi masalah utama adalah tingkat likuiditasnya, karena aset lancar yang dimilikinya hampir $80 \%$ ada pada piutang debitur. Selain itu sumber pendanaan yang diperoleh perusahaan pembiayaan umumnya berasal dari bank yang umumnya berjangka waktu pendek, sementara pembiayaan ini sifatnya berjangka menengah. Dari sisi solvabilitas, perusahaan pembiayaan juga memiliki rasio gearing sendiri (komposisi antara utang dan aktiva) yang sudah diatur sedemikian rupa justru menyebabkan struktur aktiva dan kewajiban perusahaan menjadi tidak seimbang. Dari rasio ini jelas, manajer perusahaan akan lebih mudah untuk 
mengetahui terindikasinya perusahaan mengalami financial distress. Sementara pada model lainnya seperti Springate dan Grover memiliki nilai signifikansi di atas 0,05 yaitu sebesar 0,381 dan 0,304. Berdasarkan nilai tersebut diperoleh hasil bahwa kedua model tersebut tidak memiliki pengaruh signifikan terhadap probabilitas terjadinya financial distress pada perusahaan pembiayaan. Dapat dilihat rasio yang digunakan hanya fokus pada rasio profitabilitas. Hal ini tidak dapat menggambarkan kondisi keuangan perusahaan pembiayaan secara menyeluruh jika hanya terfokus pada perolehan laba. Perolehan laba tidak serta merta mampu memberikan gambaran kemungkinan suatu perusahaan mengalami kesulitan keuangan, karena pada dasarnya setiap pengguna laporan keuangan selalu menganggap bahwa perusahaan yang memperoleh laba berarti tidak mengalami kesulitan keuangan.

\section{KESIMPULAN DAN SARAN}

\section{Kesimpulan}

1. Pengujian menggunakan teknik analisis regresi logistik diperoleh bahwa secara simultan model Springate, Zmijewski dan Grover berpengaruh signifikan terhadap probabilitas terjadinya kondisi kesulitan keuangan pada perusahaan pembiayaan yang terdaftar di Bursa Efek Indonesia tahun 2013-2017.

2 Secara parsial hanya model Zmijewski yang berpengaruh positif dan signifikan terhadap probabilitas financial distress perusahaan dengan nilai $\alpha=5 \%$. Sedangkan model lainnya tidak berpengaruh signifikan terhadap probabilitas terjadinya financial distress pada perusahaan pembiayaan yang terdaftar di Bursa Efek Indonesia tahun 2013-2017.

3. Koefisien determinasi dari Nagelkerke $R$ Square sebesar 0,606, dikatakan variasi varia- bel independen untuk menjelaskan variabel dependennya adalah sebesar $60,6 \%$. Sisanya sebesar 39,4\% dapat dijelaskan oleh faktorfaktor lain yang tidak diikutsertakan dalam model penelitian.

4 Peluang klasifikasi perusahaan yang tidak mengalami kesulitan keuangan (financial distress) sebanyak 43, sedangkan pengamatan sesungguhnya hanya 37 perusahaan. Klasifikasi debitur yang mengalami financial distress ada 32 , dan pada pengamatan sesungguhnya ada 26 perusahaan. Maka peluang persentase keakuratan secara keseluruhan sebesar $84 \%$.

\section{Saran}

Berdasarkan hasil penelitian, peneliti menyarankan beberapa hal berikut.

1. Peneliti berikutnya agar dapat menambah model prediksi kesulitan keuangan lain seperti Fullmer H-Score, Ohlson, dan dapat menggunakan teknik pengujian dengan uji beda untuk membandingkan hasilnya satu sama lain.

2. Untuk objek perusahaan pembiayaan hendaknya peneliti lebih fokus pada struktur keuangan perusahaan terutama dari hal perbandingan utang dan piutang perusahaan. Karena pada dasarnya, komposisi keuangan perusahaan pembiayaan ini tidak sama dengan perusahaan lainnya.

3. Peneliti selanjutnya dapat menambah rentang periode pengamatan lebih panjang untuk dapat menggeneralisasi hasil penelitian secara keseluruhan.

\section{DAFTAR PUSTAKA}

Adriana, A.N. 2012. Analisis Prediksi Kebangkrutan Menggunakan Metode Springate pada Perusahaan Foods and Beverages yang 
Terdaftar di Bursa Efek Indonesia periode 2006-2010. E-journal Repository Akuntansi Universitas Riau. 4(1): 5-20.

Altman, E.I. 1968. Financial Ratios, Discriminant Analysis and The Prediction of Corporate Bankruptcy. The Journal of Finance. 23[4]:589-609.

Brigham, Eugene F. \& Houston, Joel F. 2012. Dasar-Dasar Manajemen Keuangan (Essentials of Financial Management). Buku Satu, Edisi Kesebelas. Jakarta: Salemba Empat.

Elrick, Helfert. A. 2003. Teknik Analisis Keuangan; Petunjuk Praktis Untuk Mengelola dan Mengukur Kinerja Perusahaan, Edisi kedelapan. Jakarta: Erlangga.

Kasmir. 2011. Analisis Laporan Keuangan. Cetakan Keempat. Jakarta: PT Raja Grafindo Persada.

Malau, S.M., et al. 2010. Prediksi Kondisi Financial Distress Debitur Sektor Perdagangan Menggunakan Binary Logit (Studi Kasus PT Bank Sumut).

Ohlson, J.A. 1980. Financial Ratios and the Probabilistic Prediction of Bankruptcy. Journal of Accounting Research. 18(1): $109-131$.

Peraturan Otoritas Jasa Keuangan Nomor 10/ POJK.05/2014 Pasal 4 tentang Penilaian Tingkat Risiko Perusahaan Pembiayaan.

Permana, Randy Kurnia, et al. Prediksi Financial Distress pada Perusahaan Manufaktur di Bursa Efek Indonesia. Jurnal Bisnis dan Manajemen. 7(2): 149-166.

Prihantini, N.M.E.D dan Maria M.R.S., 2013. Prediksi Kebangkrutan dengan Model Grover, Altman Z-Score, Springate, dan Zmijewski pada Perusahaan Food and Beverage di Bursa Efek Indonesia. E-Jour- nal Akuntansi Universitas Udayana. ISSN: 2302-8556

Qisthi, Dafi, et al. 2013. Analisis X-Score (Model Zmijewski) untuk Memprediksi Gejala Kebangkrutan Perusahaan (pada Industri Otomotif dan Komponennya yang terdaftar di BEI Periode 2009-2011). Jurnal Administrasi Bisnis (JAB). 1(2):68-77.

Swantari, A. dan Fachrul, Husein, H. 2012. Prediksi Financial Distress Berdasarkan Kemampuan Kinerja Keuangan pada Industri Property. MiTTra (Mice, Tour and Travel). 3(1): 1-18.

Syahfitriani. 2017. Analisis Akurasi Model Grover dan Model Ohlson dalam Memprediksi Financial Distress pada Perusahaan Pertambangan yang Terdaftar di Bursa Efek Indonesia (BEI) Periode 2010-2014. Skripsi. Universitas Maritim Raja Ali Haji.

Syahyunan. 2013. Manajemen Keuangan (Perencanaan, Analisis dan Pengendalian Keuangan). Medan: USU Press.

Waluyo, W.2002. Analisis Rasio-Rasio Keuangan Terhadap Prediksi Pemberian Status Kredit (Studi Empiris Kredit Komersial pada Bank "X" Cabang Bondowoso). Tesis. Semarang: Universitas Diponegoro.

Wijoyo, Nugroho Agung. 2016. Menakar Kinerja Perusahaan Pembiayaan (Kesulitan Keuangan Perusahaan Pembiayaan (Financial Distress). Jilid Kedua. Jakarta: UI-Press.

Zakiyyah, Ufi Zuhriyatuz, et al. 2014. Analisis Penggunaan Model Zmijewski (X-Score) dan Altman (Z-Score) untuk Memprediksi Potensi Kebangkrutan (Studi Pada Perusahaan Tekstil dan Garmen yang Terdaftar di (BEI) Bursa Efek Indonesia Periode 20092012. Jurnal Administrasi Bisnis (JAB), 12. 